\title{
UJI SIFAT FISIS AIR PADA ALAT FILTRASI SEDERHANA SKALA KECIL UNTUK PEMBERSIH AIR DALAM KEADAAN DARURAT
}

\author{
Rinto Suppa ${ }^{1)}$ \\ ${ }^{1)}$ Dosen Program Studi Teknik Informatika, Universitas Andi Djemma, Palopo \\ ${ }^{1)}$ rintosuppa@gmail.com
}

\begin{abstract}
Abstrak
Telah dibuat alat filtrasi air sederhana skala kecil dengan tinggi $150 \mathrm{~cm}$ dan lebar $40 \mathrm{~cm}$ yang menghasilkan debit air dengan rata-rata 4,3 liter/menit. Pada proses pembersihan air, dilakukan tiga ketebalan variasi media penyaring untuk menghasilkan sampel air yaitu konsentrasi pasir paling besar, arang paling besar, dan pasir dan arang sama besar. Sifat fisis air yang diteliti antara lain adalah kekeruhan, jumlah padatan terlarut, suhu dan $\mathrm{pH}$.

Hasil yang didapatkan untuk nilai kekeruhan (NTU) untuk air sumur berturut-turut adalah 5,073; 4,863; 10,70 NTU, untuk air dari Sungai Tello adalah 2,703; 3,473; 5,116 NTU, dan untuk air dari Sungai Abdesir adalah 14,76;23,16; 12,60 NTU. Hasil untuk jumlah padatan terlarut yang didapatkan untuk air sumur adalah 72,1; 76,1; 71,2 mg/l, untuk air dari Sunagi Tello berturut-turut adalah 95,1; 115,3; 90,3 mg/l, dan untuk sungai Abdesir adalah 90,7; 92,2; 100,2 mg/l. Untuk pengujian $\mathrm{pH}$ hasil yang didapatkan pada air sumur adalah 7,7; 8,3; dan 7,9; untuk air dari sungai Tello $\mathrm{pH}$-nya adalah 7,8;8,3; dan 8,0 dan untuk air dari sungai Abdesir adalah 8,0; 8,3; dan 8,1. Hasil yang didapatkan dari pengukuran suhu didapatkan kesemuanya berkisar antara $28,1-28,9^{\circ} \mathrm{C}$.
\end{abstract}

Kata Kunci: Alat filtrasi air sederhana skala kecil, ketebalan variasi media filtrasi, sifat fisis air.

\section{PENDAHULUAN}

Air merupakan kebutuhan yang paling utama bagi makhluk hidup. Manusia dan makhluk hidup lainnya sangat bergantung dengan air demi mempertahankan hidupnya. Jika air yang digunakan belum memenuhi standar kualitas air bersih, akibatnya akan menimbulkan masalah lain yang dapat menimbulkan kerugian bagi penggunanya.

Belakangan ini timbul masalah yang sangat krusial yaitu sulitnya mendapat air bersih dan banyaknya terjadi bencana alam di negara kita ini, baik itu banjir, tsunami, gempa bumi, gunung merapi dan sebagainya. Pada daerah bencana, sangat sulit untuk mendapatkan air bersih walaupun banyak sumber air yang tersedia pada daerah tersebut, karena sudah kotor ataupun tercemar akibat dampak yang ditimbulkan oleh bencana alam tadi. Selain itu, adanya pembangunan industry dan penjarahan hutan merupakan penyebab berkurangnya kualitas mata air dari pegunungan karena banyak bercampur limbah dan lumpur yang terkikis terbawa aliran sungai, akibatnya, air bersih terkadang menjadi "barang langka".

Ada beragam cara untuk memecahkan masalah tersebut agar kebutuhan air bersih pada daerah bencana atau dalam keadaan darurat tetap terjaga tanpa mengharapkan atau menunggu bantuan air bersih dari luar, salah satunya dengan aplikasi teknologi yang tepat guna dimana dapat menghasilkan air dengan kualitas baik, menguntungkan dan mudah digunakan. Teknologi yang digunakan meliputi pengolahan air yang dilakukan meliputi pengolahan secara fisik (filtrasi), pengolahan kimia (adsorbsi) serta desinfeksi menggunakan $U V$ (N, Awaluddin 2007).

Pada penelitian ini, alat filtrasi dibuat, lalu air hasil filtrasi akan diuji sifat fisisnya, meliputi : kekeruhan, jumlah padatan terlarut, suhu, $\mathrm{pH}$, dan debit air yg dihasilkan. Adapun bahan-bahan dan alat-alat yang digunakan untuk membuat alat filtrasi ini adalah tray aerator untuk proses aerasi, filtrasi yang terdiri dari bahanbahan silika dan zeolit serta kain kasa untuk proses penyaringan, dan tabung 
desinfeksi untuk membunuh mikroorganisme yang terkandung dalam air. Tujuan percobaan ini adalah: (1) Mendesain alat filtrasi air sederhana yang dapat menghasilkan air dengan kualitas baik, dan mudah untuk digunakan dalam keadaan darurat untuk memperoleh air bersih; (2) Menguji sifat fisis air seperti kekeruhan, jumlah padatan terlarut, suhu, dan $\mathrm{pH}$ dengan mengacu pada PERMENKES RI dan SNI; (3) Mengukur debit air yang dihasilkan.

\section{Standar Baku Kualitas Air Minum}

Standar baku kualitas air minum merupakan parameter yang digunakan untuk menentukan kualitas air minum.

kualitas air minum harus memenuhi kualitas secara fisik, kimia dan biologi :

\section{A. Persyaratan Fisik}

Air minum harus memenuhi standar uji fisik/fisika, antara lain derajat kekeruhan, bau, rasa, jumlah zat padat terlarut, suhu, warna, dan keasamannya $(\mathrm{pH})$. Syarat fisik air yang layak minum sebagai berikut :

a. Kekeruhan

Kualitas air yang baik adalah jernih (bening) dan tidak keruh. Batas maksimal kekeruhan air layak minum menurut PERMENKES RI Nomor 416 Tahun 1990 adalah 5 skala NTU. Kekeruhan air disebabkan oleh partikel-partikel yang tersuspensi di dalam air yang menyebabkan air terlihat keruh, kotor, bahkan berlumpur. Bahan-bahan yang menyebabkan air keruh antara lain tanah liat, pasir dan lumpur (N, Awaluddin 2007).

b. Tidak berbau dan rasanya tawar

Air yang kualitasnya baik adalah tidak berbau dan memiliki rasa tawar. Bau dan rasa air merupakan dua hal yang mempengaruhi kualitas air. Bau dan rasa dapat dirasakan langsung oleh indra penciuman dan pengecap. Bau busuk merupakan sebuah indikasi bahwa telah atau sedang terjadi proses pembusukan/dekomposisi bahan-bahan organik oleh mikroorganisme di dalam air. Selain itu, bau dan rasa dapat disebabkan oleh senyawa fenol yang terdapat di dalam air (Efendi 2003).

c. Jumlah padatan terlarut

Perlu diperhatikan, air yang baik dan layak untuk diminum tidak mengandung padatan terlarut dalam jumlah yang melebihi batas maksimal yang diperbolehkan $(1000 \mathrm{mg} / \mathrm{l})$. Padatan yang terlarut di dalam air berupa bahan-bahan kimia anorganik dan gas-gas yang terlarut. Air yang mengandung jumlah padatan melebihi batas menyebabkan rasa yang tidak enak, menyebabkan mual, penyebab serangan jantung (cardiacdisease), dan tixaemia pada wanita hamil (Efendi 2003).

d. Suhu normal

Air yang baik mempunyai temperatur normal, $8^{\circ} \mathrm{C}$ dari suhu kamar $\left(27^{\circ} \mathrm{C}\right)$. Suhu air yang melebihi batas normal menunjukkan indikasi terdapat bahan kimia yang terlarut dalam jumlah yang cukup besar (misalnya, fenol atau belerang) atau sedang terjadi proses dekomposisi bahan organik oleh mikroorganisme. Jadi, apabila kondisi air seperti itu sebaiknya tidak diminum.

e. Warna

Warna pada air disebabkan oleh adanya bahan kimia atau mikroorganik (plankton) yang terlarut di dalam air. Air yang layak dikonsumsi harus jernih dan tidak berwarna. PERMENKES RI Nomor 416 Tahun 1990 menyatakan bahwa batas maksimal warna air yang layak minum adalah 15 skala TCU (N, Awaluddin 2007).

f. Derajat Keasaman $(\mathrm{pH})$ 
pH menunjukkan derajat keasaman suatu larutan. Air yang baik adalah air yang bersifat netral $(\mathrm{pH}=7)$. Air dengan $\mathrm{pH}$ kurang dari 7 dikatakan air bersifat asam, sedangkan air dengan $\mathrm{pH}$ di atas 7 bersifat basa. Menurut PERMENKES RI Nomor 416 Tahun 1990, batas $\mathrm{pH}$ minimum dan maksimum air layak minum berkisar 6,58,5 . Khusus untuk air hujan, $\mathrm{pH}$ minimumnya adalah 5,5. Tinggi rendahnya $\mathrm{pH}$ air dapat mempengaruhi rasa air. Maksudnya, air dengan $\mathrm{pH}$ kurang dari 7 akan terasa asam di lidah dan terasa pahit apabila pH melebihi 7 (Suripin 2001).

\section{B. Standar Mutu Air Minum menurut PERMENKES dan SNI}

Standar baku kualitas air minum di Indonesia ditetapkan oleh sebuah Peraturan Menteri Kesehatan Republik Indonesia Nomor 416/MENKES/PER/IX1990 tertanggal 30 september 1990 yang berisi tentang syarat-syarat air layak minum. Peraturan tersebut telah disesuaikan dengan standar yang ditetapkan WHO (N, Awaluddin 2007).

Standar Nasional Indonesia (SNI) untuk kualitas air minum dari unsur fisika dapat dilihat pada tabel berikut :

Tabel 1. Kualitas air minum dilihat dari unsur fisika

SNI 01-0220-1987 (Badan Standarisasi Nasional 1978)

\begin{tabular}{ccccccc}
\hline & & \multicolumn{5}{c}{ Syarat-syarat } \\
\cline { 3 - 6 } No & Unsur fisika & satuan & $\begin{array}{c}\text { Minimum } \\
\text { yang } \\
\text { diperboleh } \\
\text { kan }\end{array}$ & $\begin{array}{c}\text { Maksimum } \\
\text { yang } \\
\text { dianjurkan }\end{array}$ & $\begin{array}{c}\text { Maksimum } \\
\text { yang } \\
\text { diperbolehkan }\end{array}$ & Ket. \\
\hline 1 & Suhu & ${ }^{\circ} \mathrm{C}$ & - & - & Suhu udara & \\
2 & Warna & Unit* & - & 5 & 50 & *Skala Pt.Co \\
3 & Bau & - & - & - & - & Tidak berbau \\
4 & Rasa & - & - & - & - & Tidak berasa \\
5 & Kekeruhan & Unit** & - & 5 & 25 & $*$ Skala silica \\
6 & p & & 6,5 & - & 9,5 & \\
7 & Zat padat & $\mathrm{Mg} / 1$ & - & 500 & 1500 & \\
& terlarut & & & & & \\
\hline
\end{tabular}

\section{Karakteristik Air Tanah}

Air tanah secara normal akan bebas dari kekeruhan dan organisme patogen. Apabila air berasal dari aquifer yang mengandung zat organik, kandungan oksigen akan terurai dan kandungan karbon dioksida akan menjadi tinggi, air akan menjadi korosif. Air tanah, memiliki karakter-karakter tertentu dan berbeda satu dengan yang lainnya. Sedangkan air permukaan kualitasnya sangat dipengaruhi oleh kondisi lingkungan dan perilaku manusia serta sanitasi sekitarnya

\section{Teknologi Pengolahan Air Menjadi Air Minum Pada Skala Rumah Tangga \\ Teknologi pengolahan air melaui beberapa tahapan yaitu :}

a. Aerasi

Aerasi merupakan istilah lain dari tranfer gas dengan penyempitan makna, lebih dikhususkan pada transfer gas (khususnya oksigen) dari fase gas ke fase cair. Fungsi utama aerasi dalam pengolahan air adalah melarutkan oksigen ke dalam air untuk meningkatkan kadar oksigen terlarut dalam air.

b. Filtrasi 
Secara umum filtrasi adalah proses yang digunakan pada pengolahan air bersih untuk memisahkan bahan pengotor (partikulat) yang terdapat dalam air. Pada prosesnya air merembes dan melewati media filter sehingga akan terakumulasi pada permukaan filter dan terkumpul sepanjang kedalaman media yang dilewatinya. Filter juga mempunyai kemampuan untuk memisahkan partikulat semua ukuran termasuk di dalamnya algae, virus, asbestos dan koloid-koloid tanah. Proses filtrasi ini terjadi dengan melewatkan air baku melalui media berporos tertentu. Media saringan ini meliputi media filtrasi dan media penyangga (N, Awaluddin 2007).

Adapun beberapa media filtrasi adalah sebagai berikut: 1)Pasir, saringan menggunakan media pasir bertujuan untuk mengurangi kandungan lumpur dan bahan -bahan padat yang ada dalam air keruh. Ukuran pasir yang digunakan sebagai penyaring bermacam-macam tergantung bahan pencemar yang akan disaring. Semakin besar bahan padat yang akan disaring maka semakin besar pula ukuran pasir yang digunakan.(2)Arang batok adalah arang yang berasal dari tempurung kelapa. Tempurung tersebut dibakar sampai menjadi arang. Arang ini juga bisa diperoleh dari pembakaran kayu. Arang batok dapat menyerap bahan-bahan kimia pencemar air. Arang batok yang berbentuk butiran juga dapat menahan benda-benda padat yang mengotori air. Fungsi utama arng adalah untuk mengurangi warna bau air kotor. (3) Abu gosok yaitu untuk keperluan rumah tangga, bahan pencampur untuk pembuatan semen portland dalam bidang industri, selain itu untuk menjernihkan air. Pemanfaatan sekam padi untuk menjernihkan air yaitu melalui proses filtrasi/penyaringan partikel, koagulasi dan adsorpsi. Akan tetapi karbon yang terkandung didalam sekam padi berfungsi sebagai koagulan pembantu dengan menyerap atau menurunkan logam - logam pada air yang tercemar (Sutra, Arie, Santosa 2008).

c. Desinfeksi

Air lewat melalui suatu pipa bersih untuk dipanaskan dengan sinar Ultra Violet. Sinar Ultra Violet $(U V)$ dapat secara efektif menghancurkan virus dan bakteri. Sistem $U V$ ini tergantung pada jumlah energi yang diserap sehingga dapat menghancurkan organisme yang terdapat pada air tersebut. Jika energi tidak cukup tinggi, maka material organisme genetik tidak dapat dihancurkan (Sutrisno dan Suciati.1987).

\section{d. Debit Air}

Debit merupakan ukuran banyaknya volume air yang dapat lewat dalam suatu wadah atau yang dapat ditampung dalam suatu tempat/wadah tiap satu satuan waktu tertentu.

\section{METODOLOGI PENELITIAN}

Penelitian dilakukan di Laboratorium PDAM Tompobalang Kab. Gowa dan Laboratorium Kualitas Air Fakultas Perikanan Universitas Hasanuddin. Alat yang digunakan pada penelitian ini adalah 1 buah ember dengan tinggi $34 \mathrm{~cm}$ dan diameter $30 \mathrm{~cm}$ digunakan sebagai bak penyaring, 3 buah loyang alumunium dengan tinggi 11 $\mathrm{cm}$ dan diameter $40 \mathrm{~cm}$ digunakan sebagai tray aerator, 1 buah pipa pvc dengan diameter 4 inci sepanjang $120 \mathrm{~cm}$ sebagai tabung disinfeksi, 1 buah gelas ukur digunakan untuk mengukur volume air, 1 buah stopwatch digunakan untuk menghitung waktu, $\mathrm{pH}$ meter untuk mengukur $\mathrm{pH}$ air, dudukan sebagai tempat bak 
penyaring dan tray aerator, 1 buah lampu germicidal $U V 10$ watt sebagai desinfeksi, 1 buah termometer untuk mengukur suhu air, 1 buah turbiditimeter untuk mengukur kekeruhan air, 1 buah TDS meter untuk mengukur jumlah padatan terlarut dalam air, Pipa bening sepanjang 2 meter, Selang plastik sepanjang 1 meter, isolasi dan lem paralon, Kabel listrik sepanjang 2 meter, dan bak penampungan air. Bahan-bahan yang digunakan pada penelitian ini adalah ijuk untuk menyaring partikel yang lolos dari lapisan sebelumnya dan meratakan air yang mengalir, arang sebagai penyerap partikel yang halus, penyerap bau dan warna yang terdapat di air, abu gosok sebagai koagulan pembantu dengan menyerap atau menurunkan logam-logam pada air, pasir untuk menahan endapan lumpur, batu kerikil sebagai bahan penyaring dan membantu aerasi oksigen, kasa nyamuk dari plastik, air yang keruh dari Sungai Abdesir sebagai sampel air, air dari Sungai Tello sebagai sampel air, dan air sumur sebagai sampel air.

\section{1) Proses Pembuatan Alat Filtrasi}

Adapun proses pembuatan alat filtrasi adalah : (1) Menyiapkan alat dan bahan, (2) Membuat dudukan untuk alat filtrasi, (3) Membuat tray aerator dengan melubangi bagian bawah loyang alumunium seperti pada gambar (1), (4)Membuat lubang pada bagian bawah ember filter untuk pemasangan pipa tempat keluarnya air. (5) Membuat tabung disinfeksi dari pipa paralon dengan meletakkan lampu germicidal $U V$ di dalamnya dan pipa bening sebagai tempat aliran air hasil filtrasi, (6) Menghaluskan arang yang dipakai sehingga menjadi bubuk arang, (7) Memasukkan dan menyusun bahan penyaring tersebut pada bak penyaring mulai dari bagian bawah ke atas berturut-turut kasa, kerikil besar $(3 \mathrm{~cm})$,kasa, ijuk $(3 \mathrm{~cm})$, kasa, pasir $(5 \mathrm{~cm})$, kasa, arang $(5 \mathrm{~cm})$, kasa, abu gosok $(3 \mathrm{~cm})$, kasa, ijuk $(3 \mathrm{~cm})$, kasa, pasir/arang $(5 \mathrm{~cm})$, kasa, kerikil $3 \mathrm{~cm},(8)$ Meyusun tray aerator 3 tingkat dan alat filter pada dudukan dengan jarak $30 \mathrm{~cm}$. (9) Menyambungkan ember filter dengan tabung desinfeksi dengan mengunakan selang plastik. (10) Alat filtrasi siap untuk dipakai.

\section{2) Proses Uji Sifat Fisis Air}

Adapun proses untuk menguji sifat fisis air adalah sebagai berikut: (1)Menyediakan alat dan bahan, (2) Membersihkan media filtrasi terlebih dahulu dengan mengalirkan air kedalam ember filtrasi secara teratur sampai air keluarannya terlihat bersih, (3) Menuangkan air sampel pada tray aerator paling atas (sebaiknya air yang dipakai sudah ditampung terlebih dahulu di bak penampungan), (4) Menyalakan lampu disinfeksi, (5) Menampung sampel air hasil filtrasi di dalam botol minuman, (6) Mengulang proses 1-5 di atas dengan menggunakan konsentrasi media filtrasi arang lebih besar sesudah itu konsentrasi pasir dan arang sama besar, (7) Mengukur kekeruhan tiap sampel air baik itu air baku dan air hasil filtrasi dengan menggunakan turbiditimeter sebanyak 3 kali, (8) Mengukur $\mathrm{pH}$ dan suhu air dengan menggunakan, (9) Mengukur jumlah padatan terlarut sebanyak 3 kali dengan menggunakan TDS meter, (10)Mengukur debit air keluaran sebanyak 3 kali dengan cara menampungnya pada gelas ukur dan meghitung waktu yang diperlukan sampai air itu penuh pada ukuran yang ditentukan pada gelas ukur tadi, (11) Mencatat semua data hasil yang diperoleh dalam bentuk format laporan. 


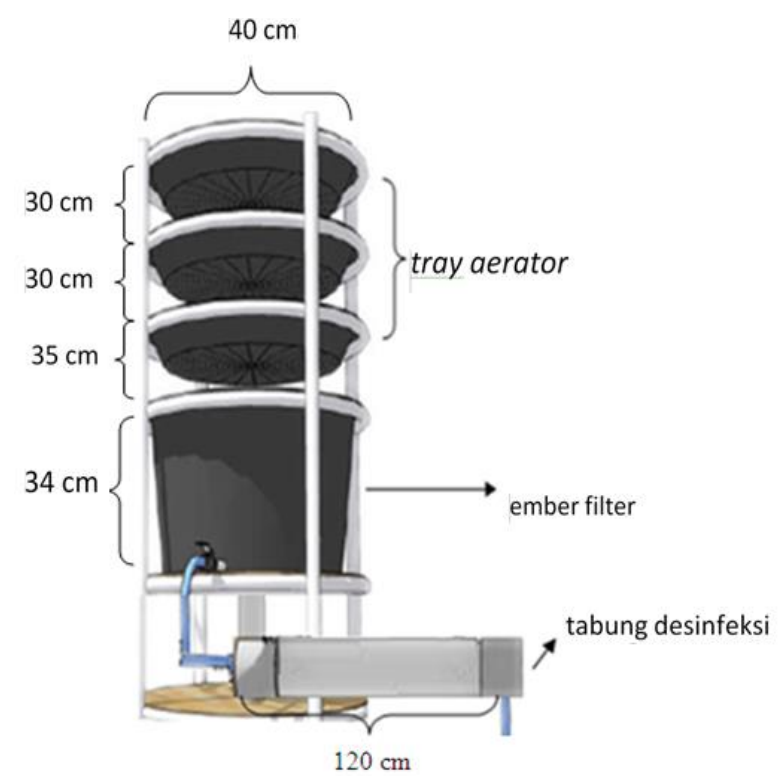

Gambar 1. Rancangan Alat filtrasi air

Diagram Alir Penelitian

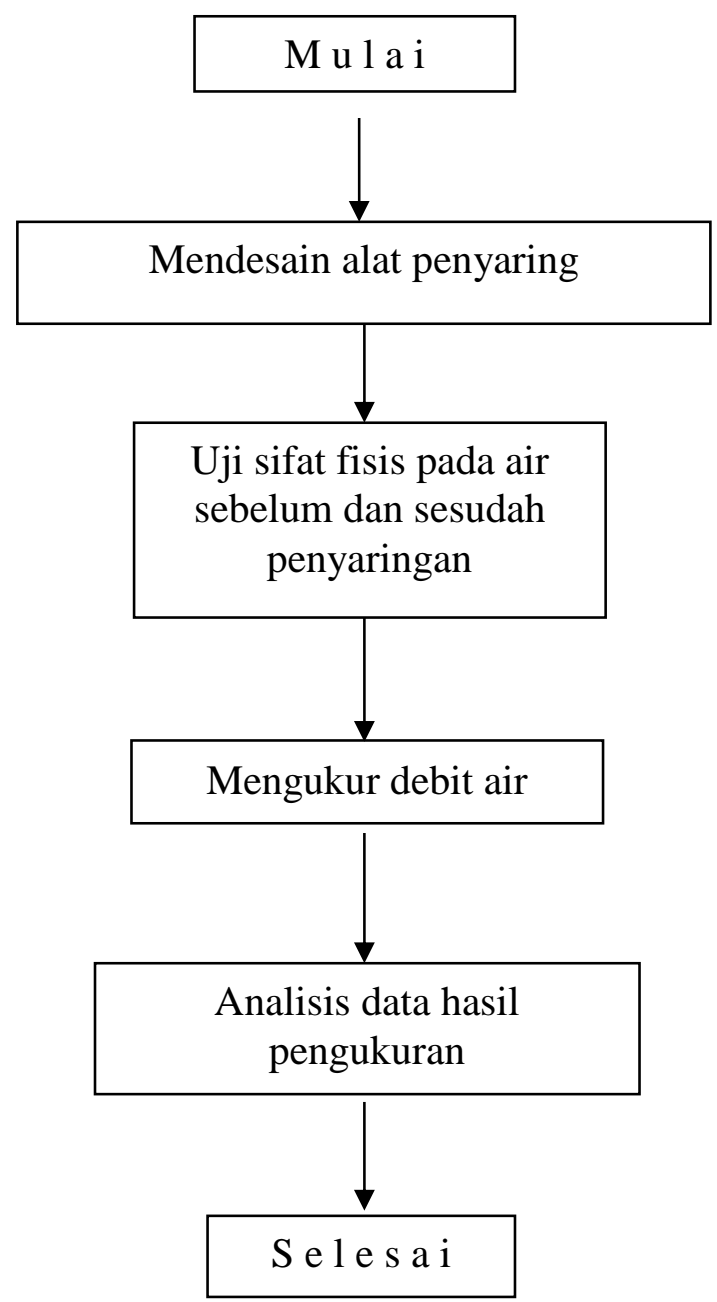




\section{HASIL DAN PEMBAHASAN}

\section{Hasil}

Dari alat filtrasi dihasilkan 9 sampel air dengan 3 variasi ketebalan media penyaring. Sampel air hasil filtrasi terdiri dari 3 sampel untuk air Sumur (A), 3 sampel untuk air Sungai Tello (B), dan 3 sampel untuk air Sungai Abdesir (C). Adapun variasi ketebalan media penyaring tersebut dapat dilihat pada tabel berikut:

Tabel 2. Keterangan variasi ketebalan media penyaring yang dilewati oleh tiap sampel

\begin{tabular}{ccccccc}
\hline & & \multicolumn{5}{c}{ Ketebalan $(\mathbf{c m})$} \\
\cline { 3 - 7 } No. & Sampel & Arang & Ijuk & Pasir & Abu Gosok & Kerikil \\
\hline 1. & $\mathrm{~A}_{1}, \mathrm{~B}_{1}, \mathrm{C}_{1}$ & 5 & 6 & 10 & 5 & 6 \\
\hline 2. & $\mathrm{~A}_{2}, \mathrm{~B}_{2}, \mathrm{C}_{2}$ & 10 & 6 & 5 & 5 & 6 \\
\hline 3. & $\mathrm{~A}_{3}, \mathrm{~B}_{3}, \mathrm{C}_{3}$ & 7,5 & 6 & 7,5 & 5 & 6 \\
\hline
\end{tabular}
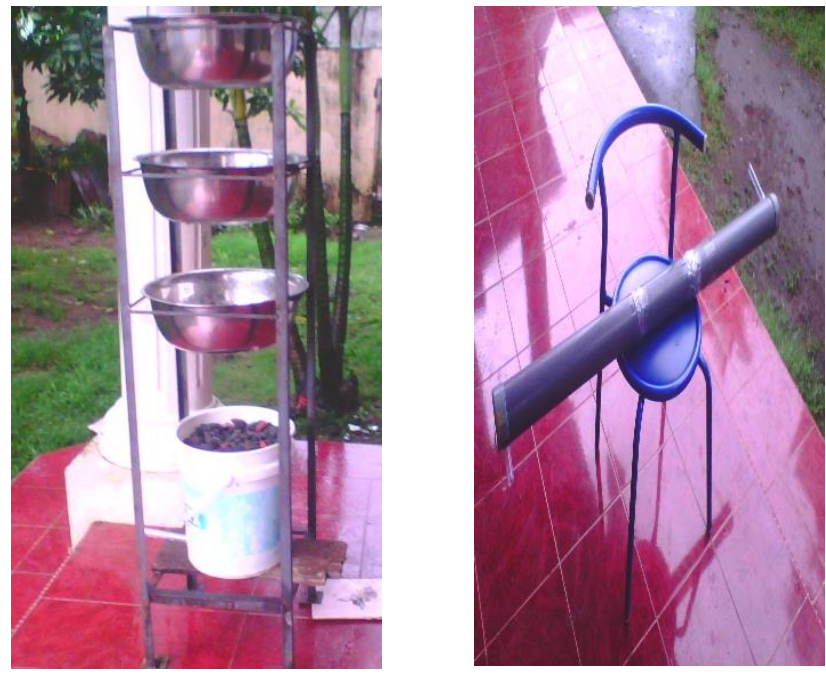

Gambar 2. hasil alat filtrasi dan desinfeksi yang dibuat

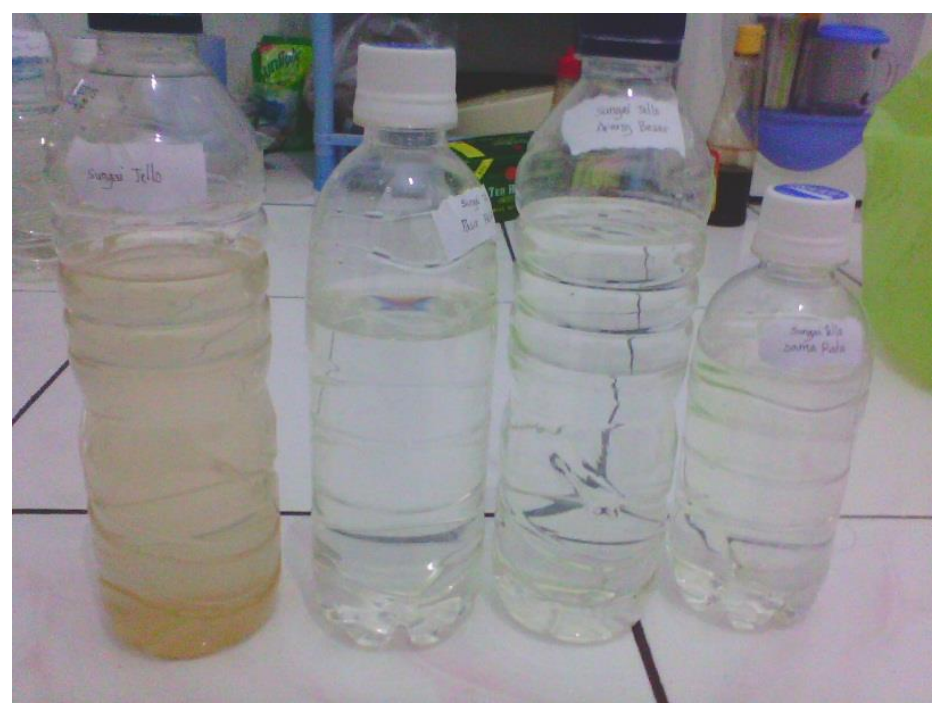

Gambar 3. Sampel air sebelum dan sesudah difiltrasi 

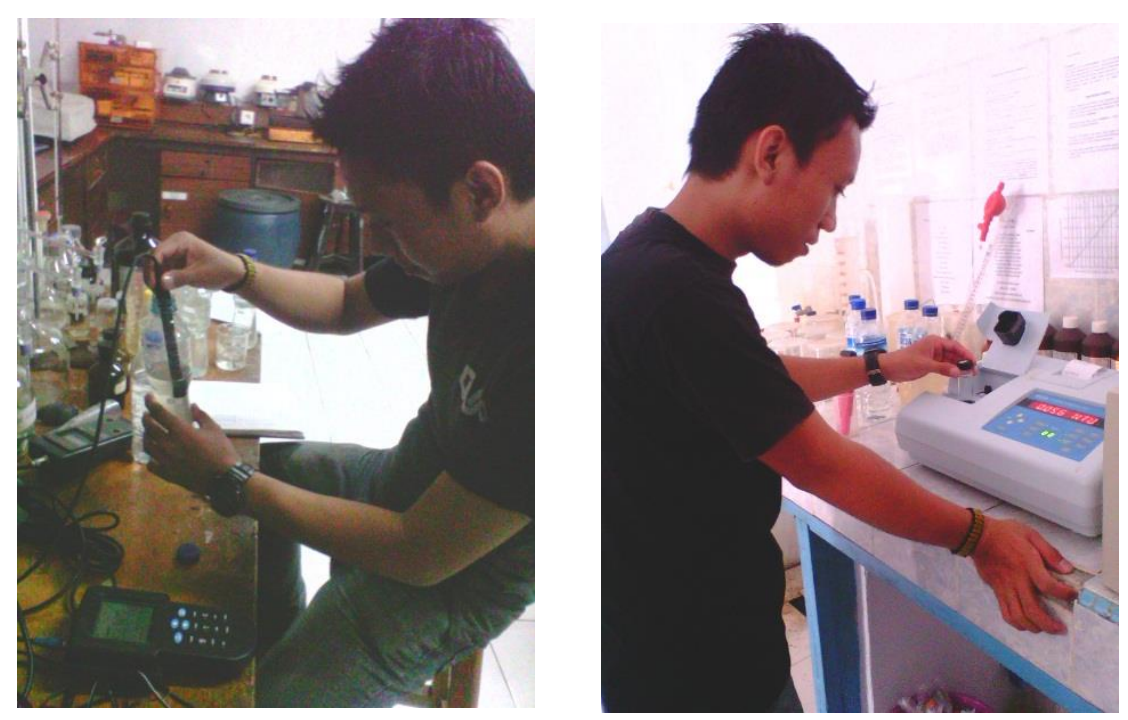

Gambar 4. Pengujian sifat fisis air menggunakan TDS meter dan Turbiditi meter

\section{Pembahasan}

a. Kekeruhan

a) Air Sumur

Dari pengujian sampel pada penelitian ini didapatkan nilai kekeruhan air baku sumur adalah 7,276 NTU dan setelah difiltrasi didapatkan hasil antara 10,700-4,863 NTU untuk sampel $A_{1}, A_{2}$, A3. Sampel $A_{1}, A_{2}$, dan $A_{3}$ masing-masing dengan kekeruhan 5,073; 4,863; dan 10,70 NTU, ketiganya memenuhi SNI 01-0220-1987 untuk syarat maksimum yang diperbolehkan yaitu maksimal 25 NTU dan hanya A2 yang memenuhi syarat maksimum yang dianjurkan yaitu 5 NTU.

b) Air Sungai Tello

Dari pengujian sampel pada penelitian ini didapatkan nilai kekeruhan air baku Sungai Tello adalah 71,13 NTU dan setelah difiltrasi didapatkan nilai kekeruhan sampel B1, B2, dan B3 masing-masing 2,703; 3,743; dan 5,116 NTU. Semua sampel air hasil filtrasi dari Sungai Tello memenuhi SNI 01-0220-1987 untuk syarat maksimum yang diperbolehkan yaitu maksimal 25 NTU dan hanya sampel B1 dan B2 yang memenuhi SNI untuk syarat maksimum yang dianjurkan yaitu 5 NTU.

c) Air Sungai Abdesir

Dari ketiga sampel yang ada, air dari Sungai Abdesir inilah yang paling keruh yaitu 105,0 NTU. Adapun hasil yang didapatkan setelah hasil filtrasi yaitu C1, C2, dan C3 masing-masing 14,76; 23,16; dan 12,60 NTU. Ketiga sampel air hasil filtrasi dari Sungai Abdesir ini tidak ada yang memenuhi SNI untuk syarat maksimum yang dianjurkan tetapi kesemuanya memenuhi SNI untuk syarat maksimum yang diperbolehkan yaitu 25 NTU.

\section{b. Keasaman $(\mathrm{pH})$}

a) Air Sumur

Dari pengukuran $\mathrm{pH}$ pada penelitian ini didapatkan nilai $\mathrm{pH}$ untuk air baku sumur adalah 6,8 dan setelah difiltrasi melalui beberapa media penyaring didapatkan nilai $\mathrm{pH}$ untuk sampel $\mathrm{A} 1$, A2, A3 masing-masing 7,7; 8,3; 7,9. Kesemua sampel pada 
air sumur ini termasuk air bakunya sendiri memenuhi SNI 01-0220-1987 untuk nilai pH yaitu 6,5-9,5 dan juga PERMENKES RI Nomor 416 Tahun 1990 yaitu batas minimum dan maksimum $\mathrm{pH}$ air layak minum berkisar 6,5-8,5.

b) Air Sungai Tello

Dari pengukuran $\mathrm{pH}$ untuk sampel ini didapatkan nilai $\mathrm{pH}$ untuk air baku dari sungai Tello adalah 7,2 dan setelah difiltrasi didapatkan hasil antara 7,8-8,3 untuk sampel $\mathrm{B} 1, \mathrm{~B} 2$, dan $\mathrm{B} 3$. Nilai $\mathrm{pH}$ untuk sampel $\mathrm{B} 1$, B2, dan $\mathrm{B} 3$ masing-masing 7,8; 8,$3 ; 8,0$. Kesemua sampel memenuhi SNI dan PERMENKES RI untuk syarat batas minimum dan maksimum untuk air minum.

c) Air Sungai Abdesir

Dari pengukuran $\mathrm{pH}$ pada penelitian ini didapatkan nilai $\mathrm{pH}$ untuk air baku dari Sungai Abdesir adalah 7,2 dan setelah difiltrasi melalui beberapa media penyaring didapatkan nilai $\mathrm{pH}$ untuk sampel $\mathrm{A} 1$, A2, $\mathrm{A} 3$ masing-masing 8,0; 8,3; 8,1. Kesemua sampel memenuhi SNI dan PERMENKES RI untuk syarat batas minimum dan maksimum untuk air minum. Adapun nilai sampel air dari Sungai Tello disajikan dalam grafik berikut :

\section{c. Jumlah Padatan Terlarut (JPT)}

a) Air Sumur

Dari pengujian sampel pada penelitian ini didapatkan jumlah padatan terlarut air baku sumur adalah $102,7 \mathrm{mg} / \mathrm{l}$ dan setelah difiltrasi didapatkan hasil antara 71,2$76,1 \mathrm{mg} / \mathrm{l}$ untuk sampel $\mathrm{A}_{1}, \mathrm{~A} 2$, A3. Sampel $\mathrm{A}_{1}, \mathrm{~A}_{2}$, dan $\mathrm{A}_{3}$ masing-masing dengan jumlah padatan terlarut 72,$1 ; 76,1$; dan 71,2 mg/l, ketiganya memenuhi SNI 01-02201987 untuk syarat maksimum yang dianjurkan yaitu $500 \mathrm{mg} / \mathrm{l}$.

b) Air Sungai Tello

Dari pengujian sampel pada penelitian ini didapatkan jumlah padatan terlarut air baku Sungai Tello adalah 47,6 mg/l dan setelah difiltrasi didapatkan nilai untuk sampel B1, B2, dan B3 masing-masing 95,1; 115,3; 90,7 mg/l . Semua sampel air hasil filtrasi dari Sungai Tello memenuhi SNI 01-0220-1987 untuk syarat maksimum yang dianjurkan yaitu $500 \mathrm{mg} / \mathrm{l}$.

c) Air Sungai Abdesir

Dari pengujian sampel pada penelitian ini didapatkan jumlah padatan terlarut air baku Sungai Abdesir adalah 29,5 mg/l dan setelah difiltrasi didapatkan nilai untuk sampel $\mathrm{C}_{1}, \mathrm{C}_{2}$, dan $\mathrm{C}_{3}$ masing-masing 90,7; 92,2; 100,2 mg/l. Semua sampel air hasil filtrasi dari Sungai Abdesir memenuhi SNI 01-0220-1987 untuk syarat maksimum yang dianjurkan yaitu $500 \mathrm{mg} / \mathrm{l}$.

\section{d. Suhu}

Dari pengukuran suhu yang dilakukan untuk ketiga sampel $\mathrm{A}, \mathrm{B}$, dan $\mathrm{C}$ ini didapatkan suhu antara $28,1^{\circ} \mathrm{C}-28,9^{\circ} \mathrm{C}$. semua sampel memenuhi SNI yaitu suhu air harus berkisar suhu kamar.

\section{e. Debit Air}

Dari pengukuran debit yang dilakukan sebanyak tiga kali dengan menggunakan gelas ukur maksimum satu liter dan stopwatch untuk menghitung waktu didapatkan rata-rata waktu untuk mengisi satu liter air adalah 0,23 menit sehingga debitnya adalah 4,3 liter/menit. 


\section{KESIMPULAN}

Telah didesain alat filtrasi sederhana skala kecil untuk pembersih air dengan tinggi $150 \mathrm{~cm}$ dan lebar $40 \mathrm{~cm}$ yang terdiri dari tiga tingkat trai aerator, ember filtrasi, dan tabung desinfeksi. Dari pengujian sifat fisis air hasil filtrasi yang telah dilakukan berupa $\mathrm{pH}$, jumlah padatan terlarut, dan suhu kesemuanya memenuhi SNI 01-0220-1987 untuk syarat yang dianjurkan dan juga memenuhi PERMENKES RI Nomor 416 Tahun 1990. Pada uji sifat fisis kekeruhan untuk sampel A1, A3, B3, C1, C2, C3 hanya memenuhi SNI untuk syarat yang diperbolehkan sedangkan untuk sampel A2, B1, B2 memenuhi SNI untuk syarat yang dianjurkan dan PERMENKES RI. Debit air yang dapat dihasilkan oleh alat filtrasi ini adalah rata-rata 4,3 liter/menit.

\section{DAFTAR PUSTAKA}

Awaluddin. 2007. Teknologi Pengolahan Air Tanah Sebagai Sumber Air Minum pada Skala Rumah Tangga. Yogyakarta: (IEM) FTSP-UII

Badan Standarisasi Nasional. 1987. SNI No. 01-0220-1987. Jakarta: Air minum.

Effendi, H. 2003. Telaah Kualitas Air. Yogyakarta: Kanisius.

Suripin. 2001. Pelestarian Sumber Daya Tanah dan Air. Yogyakarta: Andi.

Sutra, Arie, Santosa. 2008. Penggunaan Alat Sterilisasi Air Minum dengan Menggunakan Lampu Ultraviolet (UV) dalam Skala Rumah Tangga. Bandar Lampung: Ruwa Jurai.

Sutrisno dan Suciati.1987. Teknologi Penyediaan Air Bersih. Jakarta:Rineka Cipta Karya. 